Blażej Smykowski

https://doi.org/10.26881/pwe.2018.42.05

ORCID: 0000-0001-7231-2159

UAM Poznań

basmyk@amu.edu.pl

\title{
Znaczenie dla pedologii odkrycia przez Lwa S. Wygotskiego okresów kryzysu w kulturowym rozwoju dzieci i młodzieży
}

\section{Summary \\ The importance for pedology of Lev S. Vygotsky's discovery of crisis stages in the cultural development of children and youth}

The general theory of crisis stages in the cultural development of children has been outlined in the article. Nowadays such a theory seems to be extremely needed. It enables understanding of why developmental crises clearly intensify and which forms of their course favour the construction/formation or destruction of the cultural development. The formulation of such a general theory of crisis stages in the cultural development of children is of particular importance for pedagogical practices. This type of psychological reflection can become a basis of the pedagogics of the crisis stages in the cultural development of children, postulated by Vygotsky many years ago.

Keywords: cultural development, crisis stages, developmental potentials, pedology

Słowa kluczowe: rozwój kulturowy, okresy kryzysu, potencjały rozwojowe, pedologia

\section{Wprowadzenie}

Pod koniec życia Lew S. Wygotski (2001, 2002a) zaprezentował model periodyzacji okresów dzieciństwa (Valsiner, Van der Veer 1993). Mimo że w ocenach innych badaczy koncepcja ta przedstawiana jest jako niedokończona (Blunden 2008), stanowi ona jego trudny do przecenienia wkład w podwaliny tworzonej przez ówczesnych psychologów i pedagogów nowej nauki - pedologii. Pedologia miała być psychologią stosowaną i służyć pedagogom w budowaniu metodyki nauczania i wychowania bazującej przede wszystkim na wiedzy o mechanizmach rozwoju (por. Hejnicka-Bezwińska 2014). Wygotski (2001) w pierwszym wykładzie z 1933 roku skierowanym do pedagogów analizuje przedmiot pedologii. Mówi, że jest ona nauką o dziecku, a precyzyjniej o jego rozwoju. Centralnym zjawiskiem, na którym skupia się, dokonując jego analizy, jest czas i różne jego jakości. Zróżnicowanie czasów w rozwoju dziecka wiąże z różnicami w jego dynamice i strukturze. Uogólniająca analiza prowadzi go do podziału czasu rozwoju dzieci na dwa typy okresów: stabilne i kryzysu. Analiza szczegółowa z kolei prowadzi go do wyodrębnienia pięciu okresów stabilnych i sześciu kryzysu. Wygotski (2002a) w swoim modelowym uję- 
ciu okresów dzieciństwa: 1) wprowadza naprzemienność okresów kryzysu i stabilnych; 2) wyklucza z niego okres prenatalny i późny okres dorastania tj. okres od 17.-18. roku życia do całkowitej dojrzałości jako podlegające innym zasadom niż te z okresu dzieciństwa; 3) włącza okres dojrzewania płciowego do grupy okresów stabilnych, a nie kryzysu (Smykowski 2012).

Ostatecznie podział rozwoju dziecka na okresy przedstawia w następujący sposób: Kryzys narodzin, Wiek niemowlęcy (2. miesiąc życia - 1. rok życia), Kryzys pierwszego roku życia, Wczesne dzieciństwo (1. rok życia - 3. rok życia), Kryzys trzeciego roku życia, Wiek przedszkolny (3-7 lat), Kryzys siódmego roku życia, Wiek szkolny (8-12 lat), Kryzys trzynastego roku życia, Wiek dojrzewania płciowego (14-18 lat), Kryzys siedemnastego roku życia.

\section{Funkcja okresów kryzysu w rozwoju dziecka}

Celem przywołanego cyklu wykładów Wygotskiego (2001) było uzupełnienie już sprawnie i na wiele sposobów realizowanej w tym czasie pedagogiki okresów stabilnych pedagogiką okresów kryzysu. Uważał bowiem, że jeżeli sposób funkcjonowania dziecka w tych okresach zmienia się tak radykalnie, to nie może to nie zostać odzwierciedlone w sposobie odnoszenia się do niego. W innym miejscu Wygotski (2002a), kiedy zwraca uwagę nie tylko na potrzebę takiej pedagogiki, ale i na jej całkowity brak, pisze, że stosowanie do dziecka w okresie kryzysu tych samych co wcześniej praktyk, może nie tylko utrudnić odegranie kryzysowi w rozwoju swojej roli, ale i zaburzyć jego prawidłowy przebieg. Dłuższe utrzymywanie się na przykład symptomów kryzysu 3. roku życia może prowadzić do istotnych utrudnień w prawidłowym przebiegu zjawisk i procesów wieku przedszkolnego.

Przez utrudnienie Wygotski rozumie spowolnienie rozwoju. Konsekwencje tego widzi w ograniczeniu jego efektów, a więc w zjawisku prymitywizmu (Wygotski 1971; Wygotski Łuria 1993). Pisze, że jeśli na przykład kryzys 3. roku życia przebiega zbyt spokojnie, to może to prowadzić do głębokiego zahamowania woli i rozwoju afektywnej strony osobowości dziecka w wieku przedszkolnym (Wygotski 2002a). Poważniejsze konsekwencje nieuwzględniania w praktyce pedagogicznej zjawisk okresów kryzysu mogą dotknąć szczególnie trudnych w wychowaniu dzieci. Wygotski (1983) pisze, że środki z powodzeniem stosowane $\mathrm{w}$ wychowaniu jednych dzieci w przypadku trudnego dziecka są bezużyteczne. Napotykają z jego strony na opór. Kategoria trudne dziecko czy trudne $w$ wychowaniu to terminy bardzo pojemne i w związku z tym niełatwo wskazać jedną tego przyczynę. Najważniejsze według niego to deficyty w uzdolnieniach i w nastawieniu. Wygotski uważa, że nieadekwatne postępowanie z dzieckiem trudnym w wychowaniu w okresie kryzysu może spowodować nasilenie się trudności, kiedy w okresach kryzysu stosowana jest pedagogika okresów stabilnych do nacisków wewnętrznych, wynikających z przeżywania kryzysu, dołączają się bowiem naciski zewnętrzne wynikające ze stosowania pedagogiki okresów stabilnych. Pedagogika okresów stabilnych wykorzystuje 
bowiem koncept Strefy najbliższego rozwoju (np. Tudge, Scrimsher 2003; Chaiklin 2003; Dolya 2007; Filipiak 2015). Działa zgodnie z metodą podwójnej stymulacji (Wygotski 1971), która ma charakter próby funkcjonalnej (Smykowski 2012; 2017). Bazuje na stawianiu dziecku zadań aktualnie zbyt trudnych dla niego i rozwijaniu u niego umiejętności posługiwania się kulturowymi środkami pomocniczymi. Wygotski (1971) uważa, że sensem każdej metodyki wychowania i nauczania powinno być pokonywanie sprzeczności, barier, ograniczeń. Tego typu sytuacja u niektórych dzieci, szczególnie u tych, którym brakuje umiejętności albo mają złe nastawienie (Wygotski 1983), może prowadzić do przeciążenia, a w skutek tego do pojawiania się destrukcyjnych form funkcjonowania.

Celem stosowania wiedzy na temat okresów kryzysu w praktyce pedagogicznej miało być nie tyle unikanie prymitywizacji czy patologizacji przebiegu i efektów rozwoju dziecka, co stymulowanie rozwoju. Wygotski (2001; 2002a) uważa, że kryzysy stanowią siłę napędową dziecka, że to one, w kluczowy sposób, określają jakość procesów rozwojowych zachodzących w następujących po nich okresach stabilnych. W kryzysach upatruje źródło emancypacji dziecka. Im bardziej dziecku uda się w okresie kryzysu uniezależnić od wcześniejszych zależności, tym większe będzie w kolejnym okresie stabilnym pole do rozwoju dowolności jego zachowań i przebiegu jego procesów psychicznych. Należy pamiętać, że w koncepcji Wygotskiego (1971) dowolność oznacza specyficzny sposób uniezależnienia się, wraz z wiekiem, od innych ludzi. To uniezależnienie związane jest z samodzielnością w sensie zewnętrznym, ale nie wewnętrznym. Dziecko w kolejnych okresach, ucząc się od innych, staje się coraz bardziej niezależne od ich fizycznej obecności i coraz bardziej wewnętrznie od nich zależne poprzez fakt posługiwania się, przy rozwiązywaniu zadań, narzędziami od nich przejętymi. Wygotski (2001), pisząc o zmianach, jakie zachodzą w społecznej sytuacji dziecka w okresach kryzysu, zwraca uwagę na interakcję między właściwościami dziecka i dorosłego. Dziecko w okresie kryzysu zmienia się radykalnie, ujawnią się jego nowe potencjały, których jednak nie potrafi w tym czasie w sposób konstruktywny wykorzystać. W okresach kryzysu robi to raczej destrukcyjnie. Drogą powrotu na drogę kulturowego rozwoju jest zainteresowanie (Wygotski 2002f) sposobami ich wykorzystania, którymi dysponują otaczający dziecko dorośli. Jeżeli to nastąpi, destrukcyjne formy funkcjonowania, wytworzone przez dziecko w okresie kryzysu, zastępowane są przez konstruktywne, nabywane w procesie uczenia się od innych w okresie stabilnym. Tę dialektykę tendencji do emancypacji ujawnioną w okresie kryzysu i do socjalizacji w okresie stabilnym Wygotski (2002d) opisuje, analizując na przykład funkcję zabawy w rozwoju kulturowym dziecka w wieku przedszkolnym. Pisze, że dziecko równocześnie działa po linii najmniejszego i największego oporu, a więc dla realizacji swoich pragnień, ale i zgodnie z regułami życia społecznego. Ta konfliktogenna przestrzeń określa zakres rozwoju dziecka w okresach stabilnych. Trwają one dużo dłużej niż okresy kryzysu. W tym czasie bowiem dziecko musi opanować kulturowe środki radzenia sobie z konfliktami wieku rozwojowego. Im większy dystans między sprzecznymi tendencjami u dziecka, tym większą psychiczną pracą ma ono do wykonana, ale i tym trudniejsze zadanie, związane z wychowaniem i nauczaniem, stoi przed otaczającymi je dorosłymi. 


\section{Struktura i dynamika rozwoju dziecka}

Wygotski (1971; 2001), wyjaśniając strukturę i dynamikę rozwoju w okresach dzieciństwa, wykorzystuje wiedzę na temat psychologii pola Kurta Lewina i swoje doświadczenie wynikające z wieloletniego zainteresowania sztuką w ogóle, a szczególnie literaturą i teatrem (Wygodska 1980). Prezentuje, trochę przez analogię, poszczególne okresy dzieciństwa jak sceny rozwoju. Sugeruje, że od początku życia dziecka na scenie jego rozwoju obecne są, w sposób niezróżnicowany, wszystkie jego składowe. W odruchu bezwarunkowym noworodka obecne są wszystkie, wyodrębniające się w dalszym rozwoju, składowe charakteryzujące dowolne formy funkcjonowania dorosłego człowieka. Każdy okres w rozwoju dziecka odpowiedzialny jest za wyodrębnienie się określonej formacji zjawisk. Te Wygotski (2002a) określa jako centralne linie rozwoju w danym okresie. Pozostałe pełnią w tym czasie rolę linii pobocznych. Rozwijają się poprzez swoje powiązanie w strukturze z centralnymi. Każde zjawisko istotne dla rozwoju ma swój czas bycia centralnym. Wyodrębnia się wtedy z dalszego planu rozwoju, by odgrywać, przez pewien czas, w nim pierwszoplanową rolę. Według Wygotskiego (2001; 2002a) okresy kryzysu są czasem tego rodzaju zmian na scenie rozwoju. Jedne procesy, wcześniej pierwszoplanowe, wycofują się na dalszy plan, inne wcześniej znajdujące się na dalszym planie, wysuwają się na plan pierwszy. Tak restrukturowana w rewolucyjnych procesach okresu kryzysu struktura podlega dalszym, ewolucyjnym już procesom przekształceń w okresach stabilnych. Rozwój na danym etapie rozpoczyna więc rewolucja, a nie go kończy. Kryzys otwiera nowe możliwości rozwoju. W tym sensie koncepcja okresów kryzysu Wygotskiego odwołuje się do problemu podnoszonego przez Baldwina (Valsiner, Van der Veer 1993) roli w rozwoju ontogenetycznym zarówno problemów inwolucji, jak i ewolucji. Kryzys jest równocześnie związany z obumieraniem czegoś, ale i powstawaniem czegoś nowego (Wygotski 2002f). Tego typu zmiana miejsc, między figurami rozwoju, zachodzi w dzieciństwie kilkakrotnie.

Okresy stabilne są jednolitą, stabilną całością (Wygotski 2002f). Rozwój w tych okresach dokonuje się przez mikroskopijne zmiany, których kumulacja doprowadza, po przekroczeniu pewnego punktu, do ujawnienia się nowej formy rozwojowej charakterystycznej dla tego wieku (Wygotski 2002a). Dopiero więc porównanie tego, jakim dziecko było na początku danego okresu stabilnego z tym, jakim jest na jego końcu, pozwala zauważyć, jak duże zaszły zmiany. W okresach kryzysu jest więcej dynamiki, a i więcej potencjałów rozwojowych niż w okresach stabilnych. Przejście na przykład od stojących na niższym poziomie w rozwoju reakcji nawykowych do intelektualnych związane jest z czymś, co Wygotski (1971) określa jako „krótkie spięcie”. Rozumie on przez nie gwałtowne zmiany zachodzące w jakimś skomplikowanym, centralnym mechanizmie wewnętrznym, zachodzące dzięki pobudzeniu w wielu współpracujących ze sobą ośrodkach i prowadzące do utorowania nowej drogi.

Wygotski (2001), analizując różnicę w czasie rozwoju dziecka, przeprowadza ją w sposób całościowy. Krytykuje analizę rozczłonkowującą złożone całości na części i proponuje poszukiwanie podstawowych jednostek analizy, w których zachowane są wszystkie części analizowanej całości (Smykowski 2012). Będąc równocześnie pedagogiem, psy- 
chologiem i w jakimś zakresie też lekarzem, z łatwością realizuje swoje postulaty dotyczące analizy złożonych całości. Nie rozkłada przedmiotu swojej analizy na składowe czy aspekty. Łącznie stosuje wiedzę z zakresu psychologii, pedagogiki czy biologii. Tworzy wiedzę o rozwoju dzieci w ogóle.

Każdy okres w rozwoju Wygotski (2002a) traktuje jak odmienną całość, charakteryzującą się odmienną strukturą i dynamikę, ale i ujmuje w jednolitym procesie rozwoju. Z niego wynika ogólna zasada. Ta, na ogólnym poziomie, definiuje mechanizm funkcjonowania dziecka, przejawia się w specyficzny, różny sposób w każdym z okresów rozwoju. Ta specyficzna forma realizacji ogólnej zasady określa sposób, w jaki dziecko przeżywa, w jaki sposób działa na niego otoczenie, a szczególnie jak wygląda jego sytuacja społeczna, jak wygląda struktura jego funkcji, jego osobowość itd. Wygotski (2002e) postuluje traktowanie przeżycia jako podstawowej jednostki analizy związku między osobowością dziecka a środowiskiem. Kryzys stanowi przełom wyrażający się w przejściu od jednego sposobu przeżywania do drugiego. Istotą każdego kryzysu, jak twierdzi L.S. Wygotski, jest „,...) przebudowa w sferze przeżyć wewnętrznych, przebudowa związana ze zmianą podstaw określających stosunek dziecka do środowiska. Szczególnie dotyczy to zmiany potrzeb i motywów ukierunkowujących zachowania dziecka. [...] Zmianie ulega przy tym również środowisko, tzn. stosunek dziecka do środowiska. Co innego zaczyna je interesować, powstają nowe formy działalności" (Wygotski 2002e:177).

Celem pedologii jest według Wygotskiego opis tych całości, procesu ich powstawania i mechanizmu działania. Ma ona w praktycznych działaniach uwzględniać zarówno różnicowanie okresów w rozwoju dziecka, jak i łączyć je w jednolity proces przekształceń, przechodzenia jednego w drugie. Wygotski (1971) pisze, że stosunki między etapami w rozwoju mają charakter dialektyczny. Zjawiska okresu wcześniejszego są negacją zjawisk okresu następnego. Cechy właściwe poprzedniemu stadium zostają zniesione, znikają lub niekiedy przechodzą do stadium wyższego. To zniesienie zjawisk okresu poprzedniego widoczne jest zarówno w okresach kryzysu, jak i stabilnych.

Wygotski (2002g) pisze, ze rozwój we wszystkich fazach dzieciństwa następuje w wyniku poważnych konfliktów i zderzeń, przebiega w nieustannym konflikcie form biologicznych i kulturowych. Walka przeciwieństw stanowi w jego koncepcji jądro dynamiki rozwoju. Przeciwstawianie się zjawisk okresu kryzysu zjawiskom okresu stabilnego, ale i stabilnego zjawiskom okresu kryzysu prowadzi, w pomyślnym wariancie rozwoju, do wytworzenia nowych zjawisk będących ich syntezą. Mechanizm ten powtarza się cyklicznie. $\mathrm{W}$ efekcie raz jedne, raz drugie zjawiska stają się figurą na scenie rozwoju, powodując, że im przeciwne stają się dla nich tłem.

Wygotski (1971), stosując do wyjaśniania zasad rozwoju podejście geologiczne, wskazuje, że zjawiska charakterystyczne dla wcześniejszych całości włączane są w późniejsze, zachowują się w nich w jakiejś formie, są w nich ,ppogrzebane”. Wytwory okresów kryzysu i okresów stabilnych mają inne znaczenie dla rozwoju i w związku z tym zachowują się w innej formie. Wytwory okresów kryzysu mają przejściowy charakter, wraz z odegraniem swojej roli zanikają. Są jakby „pochłaniane” przez wytwory kolejnego stabilnego okresu. 
Nie mają w kolejnych okresach samodzielnego bytu, działają przez nowo powstające wytwory okresu stabilnego, są w nich, w sensie geologicznym, ukryte. Na przykład zjawisko negatywizmu okresu kryzysu 3. roku życia działa w kolejnych okresach stabilnych jako podstawa postawy sceptycyzmu, dystansowanie się poznawcze i emocjonalne, krytycyzm.

\section{Odkrycie okresów kryzysu w rozwoju dzieci}

Odkrycie normatywności kryzysu rozwojowego związane było z powiązaniem zachowań o negatywnym charakterze, powtarzających się u dzieci w tym samym wieku, z zachodzącymi wtedy procesami psychicznymi o charakterze rozwojowym, a nie jak przedtem klinicznym. Te pierwsze zaczęto traktować jako symptomy tych drugich. Uznano, że są one zewnętrznymi przejawami procesów zachodzących w prawidłowo przebiegającym procesie rozwoju. Tym samym negatywne charakterystyki zachowania zostały uznane za przejaw pozytywnych zmian wewnętrznych. Wygotski zwracał uwagę, że „(...) negatywna treść rozwoju pojawiająca się w okresie kryzysu jest tylko zwrotną, ujemną stroną pozytywnych zmian osobowości stanowiących główny, podstawowy sens każdego kryzysu" (2002: 72). W niedługim czasie, w sprzyjających warunkach, symptomy negatywne przeważnie wygasają, a coraz wyraźniej zaznacza się pozytywne ustosunkowanie do otoczenia. Słabnięcie negatywnych symptomów jest sygnałem zbliżającego się końca okresu kryzysu. Wraz z tym zwiększa się możliwość działań o charakterze nauczania i wychowania. Wygotski uważa, że kryzysy w rozwoju zachodzą w sposób naturalny, spontaniczny, nie są spowodowane istnieniem ,„(..) jakiejś jakości warunków zewnętrznych, lecz własną wewnętrzną logiką rozwoju" (2002a: 69). Ich symptomy pojawiają się nagle i szybko eskalują, po czym równie nagle słabną. Całość trwa przeważnie dwa, trzy miesiące. Wskazuje jednak, że ich obraz zależy od sytuacji. W zależności od warunków może być skrajnie różny. Niektóre dzieci mogą nie ujawniać żadnych trudności, inne tak. Wygotski (2002a) skłania do oceny względnej trudności wychowawczych poprzez odniesienie tego, jak jest, do tego, jak było wcześniej. Takie podejście pozwala zauważyć pogorszenie, nawet jeśli na tle innych rówieśników jest ono minimalne.

Zdaniem Wygotskiego (2001, 2002a) różnica stopnia zaawansowania pedagogiki pod względem radzenia sobie z rozwojem dziecka w okresach stabilnych i kryzysu wynika z tego, że symptomy zjawisk rozwojowych charakterystycznych dla poszczególnych okresów kryzysu zostały odkryte później niż okresów stabilnych i nie wszystkie w tym samym czasie. To, że psychologia i pedagogika nie zauważały ich, wynikało z rzadkości przypadków nasilonych symptomów. Ich pojawianie się też traktowano nie jako normę, ale jako wyjątek, nie jako powiązane z rozwojem, ale z patologią.

\section{Dynamika okresów kryzysu}

Zjawiska każdego okresu kryzysu stanowią genetyczną podstawę następującego po nim okresu stabilnego, stanowią most łączący jeden okres stabilny z drugim (Wygotski 
1984b). Stosunkowo łatwo określić granice początku i końca okresów stabilnych. Są one zauważalne, choć nie w każdym przypadku są tak samo wyraźne. Okresy kryzysu z kolei, ze względu na ich specyficzną dynamikę, najlepiej określać ustalając najpierw punkt kulminacji symptomów, a następnie przyjąć za początek bezpośrednio poprzedzające go półrocze, a za koniec półrocze następujące bezpośrednio po nim.

Okresy stabilne mają wyraźnie dwuczłonową strukturę i dzielą się na dwa stadia. Okresy kryzysowe mają wyraźnie widoczną trzyczłonową strukturę i w ich skład wchodzą trzy, powiązane ze sobą fazy: przedkryzysowa, kryzysowa i pokryzysowa. W fazie przedkryzysowej zarówno aktualna forma napędu, jaki i aktualna struktura form aktywności psychicznej i praktycznej przestają pełnić centralną rolę w procesach rozwoju. W fazie kryzysowej następuje ich negacja pozwalająca na ukonstytuowanie się w fazie pokryzysowej nowej formy napędu, jak i nowej strukturze aktywności psychicznej i praktycznej w centralnej roli. Sama faza kryzysowa okresu kryzysu trwa około dwa, trzy miesiące. Cały okres kryzysu około roku.

Trzy cechy charakteryzują w ogóle każdy z okresów kryzysu: gwałtowny przebieg, trudności wychowawcze i negatywny charakter. Kryzys ujawnia się w sposób nagły i bardzo trudno precyzyjnie przewidzieć moment jego nadejścia i końca, gwałtownie się nasila, aż do kulminacji przeważnie w środku danego wieku rozwojowego. „W tych okresach w stosunkowo krótkim czasie (...) skumulowane są gwałtowne, fundamentalne i przełomowe zmiany w osobowości dziecka. W bardzo krótkim czasie całkowitej zmianie ulegają podstawowe cechy dziecięcej osobowości. Rozwój przybiera gwałtowny, burzliwy, czasami katastroficzny charakter; zarówno pod względem tempa zachodzących zmian, jak i ich znaczenia przypomina rewolucyjny tok wydarzeń" (Wygotski 2002a:68). One właśnie stanowią punkty zwrotne w rozwoju dziecka, przybierając czasami formę ostrego kryzysu. W trakcie jego przebiegu dzieci jakby „wypadają” z systemu wpływów pedagogicznych, stają się trudne $\mathrm{w}$ prowadzeniu. $\mathrm{W}$ wieku szkolnym na przykład zbliżanie się okresu kryzysu ujawnia się zmniejszeniem tempa wykonywania czynności, postępującym spadkiem zainteresowania zajęciami szkolnymi oraz ogólnym obniżaniem się zdolności do działania (Wygotski 2002a). Rozwój w okresie kryzysu przybiera postać destrukcji. Dziecko jakby zatrzymuje się, a na pierwszy plan wysuwają się procesy atrofii i zwijania, dezintegracji i rozpadu osiągnięć poprzedniego okresu w rozwoju. W okresach kryzysu dochodzi do pogorszenia wyników działań wykonywanych przez dziecko. Dzieje się tak, ponieważ stare nawyki, które przestały być zaangażowane w stare zainteresowania (te zanikają w okresie kryzysu), nie określiły jeszcze swojego miejsca w nowej strukturze organicznych popędów. Nie została określona, bo same popędy nie weszły jeszcze w nowy typ związków z otoczeniem, a stare zostały rozerwane. W zakresie zainteresowań powstaje jakby pustka, stare obumierają, a nowe jeszcze nie powstały (Wygotski 2002f).

Wygotski (2001) zwracał szczególną uwagę na znaczenie trzech okresów w pracy pedagogów: kryzysu 3. roku życia, 7. roku życia i 13. roku życia. Uznawał je za kluczowe dlatego, że poprzedzają trzy kolejne etapy nauczania: przedszkolnego, szkolnego i gimnazjalnego. Dla nauczania na wczesnych etapach z kolei kluczowe są dwa pierwsze z nich. 
Trzeba jednak pamiętać, że jakość poradzenia sobie przez dziecko ze zjawiskami nimi objętymi ujawnia się w sposób szczególny w kryzysie 13. roku i wieku dojrzewania płciowego (Wygotski 2001).

\section{Kryzys 3. roku życia}

Treści dotyczące kryzysu 3. roku życia Wygotski (2001; 2002c) przedstawiał na wykładach dla pedagogów i psychologów. Wynika z nich, że sensem procesów rozwojowych, zachodzących w tym okresie, jest zmiana pozycji dziecka w sytuacji społecznej. W okresie noworodkowym i niemowlęcym dziecko swoje pragnienia realizowało zgodnie z naturalnymi wzorcami (Wygotski 1984a), w okresie wczesnego dzieciństwa zgodnie z wzorcami kulturowymi (Wygotski 2002b). Kryzys 3. roku życia inicjuje proces bycia aktywnym w tworzeniu swojej sytuacji psychicznej i społecznej. Wszystkie symptomy są świadectwem zachodzenia temu służących procesów.

Centralnym symptomem kryzysu 3. roku życia, z grupy pierwszorzędowych, jest negatywizm. Jest on rozumiany przez Wygotskiego jako akt o społecznym charakterze. Ujawnia się w sytuacjach proponowania dziecku czegoś przez dorosłego czy proszenia o coś. Negatywizm kierowany jest do dorosłego, a nie na treść tego, co jest mu proponowane czy tego, o co jest proszone. W pierwszym planie widać przeciwstawienie się dziecka drugiemu człowiekowi, ale w drugim ma miejsce przeciwstawienie się swoim popędom. Negatywizm jest bowiem odmową czegoś, czego dziecko pragnie dlatego, że poprosił je o to czy zaproponował mu to dorosły. W tego typu sytuacji dochodzi do sprzeczności tendencji. Dążąc do przeciwstawienia się dorosłemu, dziecko musi przeciwstawić się swojemu pragnieniu. Jedynie postępując wbrew jednej tendencji, ma szansę zrealizować drugą. Dzieje się tak, ponieważ dziecko nie dysponuje jeszcze w tym wieku umiejętnością godzenia sprzecznych tendencji. Ta umiejętność będzie formowała się w wieku przedszkolnym (Wygotski 2002d). Również w uporze dziecka, drugim z pierwszorzędowych symptomów kryzysu 3. roku życia, widać zarówno społeczne odniesienie jego zachowań, jak i tendencję do działania wbrew aktualnym popędom, z tym, że odniesienie to nie dotyczy innych ludzi, ale siebie samego. Upór bowiem ma miejsce wtedy, kiedy dziecko obstaje przy czymś nie dlatego, że tego bardzo pragnie, ale dlatego, że to ono tego zażądało. Dziecko w uporze przeciwstawia się swoim aktualnym pragnieniom, starając się zachować wierność sobie.

Do pierwszorzędowych symptomów kryzysu 3. roku życia, oprócz negatywizmu i uporu, Wygotski zalicza jeszcze krnąbrność i samowolę. Krnąbrność również jest symptomem tendencji do przeciwstawiania się. Nastawiona jest jednak przeciw zasadom wychowania, przeciw sposobowi życia. Niezadowolenie dziecka wyraża się w sformułowaniu ,tak, ale!”. Symptom ten nie jest wyrazem ustosunkowania się do jakiejś osoby czy rzeczy, ale do całej dotychczasowej swojej sytuacji. Dziecko w ten niejednoznaczny sposób ustosunkowuje się zarówno do tego, co je do tej pory interesowało (np. zabawki, zajęcia) czy tego, co regulowało jego zachowania (np. normy, zakazy, nakazy). Krnąbr- 
ność jest zewnętrznym wyrazem dążenia do realizacji własnego pragnienia - postawienia na swoim. Z kolei samowola to tendencja dziecka do niezależności. Dziecko w tym wieku chce wszystko robić samo.

Podobną jak krnąbrność tendencję ujawniają symptomy określane jako drugorzędowe. Sprzeciw - bunt, deprecjacja oraz despotyzm-zazdrość ujawniają, że dziecko w kryzysie 3. roku walczy z otoczeniem, jawnie sprzeciwia się, jest z nim w konflikcie. Deprecjonuje wartość kochanych ludzi, lubianych zabawek, określając je słowami czy terminami, które oznaczają wszystko to, co słabe i negatywne, mimo że nie doświadczyło z nimi żadnej nieprzyjemności. Dziecko do tej pory uległe, łatwe w prowadzeniu ujawnia tendencje do despotycznej władzy nad innymi. W stosunku do rodzeństwa i rówieśników, mimo tego, że nie dają oni mu do tego powodu, ujawnia zazdrość.

\section{Kryzys 7. roku życia}

Również te treści Wygotski $(2001 ; 2002$ e) przedstawił w tym samym cyklu wykładów. Twierdzi, że w okresie kryzysu 7. roku życia, szczególnie u tych dzieci, które miały trudne dzieciństwo, dochodzi do głębszych zmian i bardziej złożonych niż te, które zachodzą w kryzysie 3. roku życia. Tak jak w okresie kryzysu 3. roku życia dziecko ujawnia tendencję do kontrolowania swojego otoczenia, a brak umiejętności ku temu skutkuje szeregiem negatywnych konsekwencji, tak w okresie kryzysu 7. roku życia ujawnia ono tendencję do kontrolowania swoich zachowań. I tu również z braku umiejętności nie radzi sobie z tym. Jego niektóre zachowania stają się dziwaczne. Dziecko wygłupia się, robi z siebie błazna, czym wywołuje dezaprobatę. Dziecko przeglądając się w czymś, błaznuje bez związku zarówno z sytuacją, w której się znajduje, jak i z tym, co aktualnie przeżywa. To przedstawienie ujawnia głębokie zmiany dokonujące się w tym okresie - różnicowanie się wewnętrznej i zewnętrznej strony osobowości dziecka. Zaczyna na zewnątrz, w zachowaniach być inne niż wewnątrz, w emocjach. Kryzys 7. roku życia rozpoczyna dopiero ten proces, $w$ związku z czym dziecko ma poważne problemy z równoczesną kontrolą emocji i zachowań - stąd ta jego dziwaczność. Zachowanie dziecka charakteryzuje się pewną przesadą, grając, uwypukla charakterystyczne aspekty roli. Przesadę w zachowaniu Wygotski wskazuje jako symptom kryzysu 7. roku życia. Pisze, że zachowania dziecka są umyślnie niedorzeczne i sztuczne. Drugim obok przesady symptomem tego okresu jest kapryszenie. Dziecko bez widocznego powodu wyraża niezadowolenie, obraża się. Jest to efekt załamanie równowagi psychicznej. Wyraża się ono w zmienności - przede wszystkim stanów woli dziecka i jego nastroju.

Niestabilność w ustosunkowaniach dziecka powoduje, że jest ono nieprzewidywalne. $\mathrm{Z}$ chwili na chwilę zmienia zdanie na temat czegoś, mimo tego, że to, w sensie obiektywnym, nie zmieniło się. Jest to wyraz prób intelektualnego ustosunkowywania się do czegoś nie zawsze zgodnie z własnymi emocjami. Niemożność utrzymania jednej perspektywy przez dłuższy czas powoduje, że raz intelekt, raz emocje decydują o ustosunkowaniu. Dzieje się tak, ponieważ w kryzysie 7. roku życia na plan pierwszy procesów związanych 
z ustosunkowywaniem się wysuwa się tak zwany moment intelektualny. Rozrywa on, do tej pory bezpośredni, związek między przeżyciem a zachowaniem dziecka. Zachowania dziecka tracą swoją spontaniczność (Smykowski, Kleka 2017). Przestają być prostą konsekwencją doświadczanych aktualnie emocji. Dziecko przez chwilę zachowuje się zgodnie z jakimś własnym, często dziwacznym pomysłem, po czym do głosu dochodzą emocje. I tak na zmianę. Mimo dziwacznej postaci jest to prymitywny mechanizm angażowania myślenia w organizowanie swojego zachowania. Jest to zapowiedź planowania. Aktualny poziom rozwoju myślenia nie pozwala dziecku jednak zrobić tego w pełni. Ta sprawność funkcji myślenia będzie doskonaliła się w okresie szkolnym. Na ten temat Wygotski (2001) wypowiada się w wykładzie pt. „Мышление школьника” z maja 1934 roku.

Zdaniem Wygotskiego krokiem w kierunku poradzenia sobie z tendencją do kontrolowania własnych zachowań jest rozwój usensowniania i uogólniania myślenia. Dzięki temu dziecko zwiększa zakres stałości własnego ustosunkowania do zjawisk. Im ich subiektywna niezmienność jest większa, tym dłuższy czas na zaplanowanie zachowania i jego realizację. Zmiany te prowadzą dziecko do wzrostu orientacji we własnych przeżyciach - zaczyna ono rozumieć to, co się z nim dzieje w danym momencie. Przeżycie nabiera dla niego zrozumiałego sensu wtedy, kiedy zaczyna rozpoznawać swoje emocje, np., że kiedy się złości, to znaczy, że jest złe. Przeżycia, których sens został przez dziecko rozpoznany, wchodzą ze sobą w związki. Powstające w efekcie struktury sensownych dla dziecka przeżyć podlegają równocześnie procesowi uogólniania. W tym czasie dziecko zaczyna sobie w inny sposób uświadamiać treść własnego przeżycia. Introspekcja nabiera werbalnego charakteru. Dziecko spostrzega sens własnych procesów psychicznych (Wygotski 1971). Jeśli uświadomi sobie, że coś sobie przypomina, to jego własne przypominanie staje się przedmiotem jego świadomości. Te procesy jednak przebiegają w następującym po okresie kryzysu 7. roku okresie stabilnym - w wieku szkolnym.

\section{Zakończenie}

W niniejszym tekście skupiłem się na okresach kryzysu z dwóch powodów. Po pierwsze, Wygotski (2001, 2002a) pisze, że mają one szczególne znaczenie dla rozwoju, tkwi w nich potencjał do zmian o rewolucyjnym charakterze. Po drugie dlatego, że mimo upływu lat od ich odkrycia wiedza na ich temat nie jest wykorzystywana w praktyce wspomagającej rozwój dziecka. Jak pisze Wygotski (2002a), nie powstała i wtedy, i jak mi się wydaje ciągle jeszcze pedagogika okresów kryzysu. Oba powody wiążą się ze sobą. Kryzys jest okresem, w którym ujawniają się emancypacyjne tendencje. Jeżeli jako wychowawcy ich nie uwzględniamy, czy to z powodu braku na ich temat wiedzy, czy to z powodu lęku przed ich czasowo negatywnym charakterem i braku umiejętności radzenia sobie z nimi, to bardziej czy mniej świadomie, ale ograniczamy możliwości rozwojowe dziecka. Nie dajemy rozwojowi w pełni wybrzmieć. Powstrzymując tendencję emancypacyjną, zmniejszamy konflikt między nią a wzmacnianą w okresach stabilnych tendencją socjalizacyjną. W ten sposób zmniejszamy przestrzeń rozwoju dziecka, jego kompetencji odpowiedzianych za 
godzenie ich ze sobą we własnym życiu. Człowiek zarówno w sensie ontogenetycznym, jak i filogenetycznym musi być coraz bardziej gotowy do radzenia sobie ze sprzecznościami w swoim życiu.

Potrzeba odkrywania potencjałów rozwojowych człowieka każe szukać ich tam, gdzie do tej pory ich się nie spodziewano. Kryzys rozwojowy wydaje się taką przestrzenią. Studia teoretyczne i empiryczne nad jego dynamiką i strukturą pozwoliły takim badaczom, jak Wygotski, Erikson czy Riegiel zrewolucjonizować podejście do rozwoju (Smykowski 2012). Czas zrobić następny krok i ich odkrycia wprowadzić do praktyki związanej z nauczaniem i wychowaniem. Według Wygotskiego (2001) bez tego wiedza na ich temat jest bez sensu. Pedologia, której centralną część stanowi wiedza o znaczeniu kryzysu w rozwoju dziecka, nie miała być teorią, miała być nauką stosowaną.

\section{Literatura}

Blunden A. (2008), Vygotsky's unfinished theory of child development, https://www.marxists.org/ archive/vygotsky/works/comment/vygotsky-on-development.pdf.

Chaiklin S. (2003), The zone of proximal development in Vygotsky's analysis of learning and instruction. In: A. Kozulin, B. Gindis, V. Ageyev, S. Miller (eds.), Vygotsky's educational theory and practice in cultural context. Cambridge, Cambridge University Press.

Dolya G. (2007), Klucz do uczenia się. Technologia rozwoju dziecka. Warszawa, Key to Learning Polska.

Filipiak E. (2015), Budowanie rusztowania dla myślenia i uczenia się dzieci w perspektywie spoteczno-kulturowej teorii Lwa S. Wygotskiego. W: E. Filipiak (red.), Nauczanie rozwijajace we wczesnej edukacji wedtug Lwa S. Wygotskiego. Bydgoszcz, ArtStudio.

Hejnicka-Bezwińska T. (2014), Kulturowe uwarunkowania włączenia pedagogiki w zakres zainteresowań Szkoły Lwowsko-Warszawskiej. „Przegląd Pedagogiczny”, 1.

Smykowski B. (2012), Psychologia kryzysów w kulturowym rozwoju dzieci i młodzieży. Poznań, Wyd. Naukowe UAM.

Smykowski B. (2017), Eksperymentalna metoda podwójnej stymulacji w diagnozowaniu gotowości dzieci do uczenia się pod kierunkiem. „Psychologia Wychowawcza”, 11.

Smykowski B., Kleka P. (2017), Skala Spontaniczność-Reaktywność (S-RS): Konstrukcja i właściwości psychometryczne. „Polskie Forum Psychologiczne”, 1.

Tudge J. and Scrimsher S. (2003), Lev S. Vygotsky on Education: A Cultural-Historical, Interpersonal and Individual Approach to Development. In: B.J. Zimmerman, D.H. Schunk (eds.), Educational Psychology: a Century of Contributions. Mahwah, New Jersey, London, Lawrence Erlbaum Associates, Publishers.

Valsiner J. and Van der Veer R. (1993), The Encoding of Distance: The Concept of the Zone of Proximal Development and Its Interpretations. In: R.R. Cocking, K.A. Renninger (eds.), The development and meaning of psychological distance. Hillsdale, New Jersey, Lawrens Erlbaum Associates, Inc.

Wygodska G.L. (2002), O życiu L.S. Wygotskiego. W: A. Brzezińska, M. Marchow (red.), Wybrane prace psychologiczne II. Dzieciństwo i dorastanie. Dziecko w zabawie $i$ w świecie języka. Poznań, Zysk i S-ka. 
Wygotski L.S. (1971), Wybrane prace psychologiczne. Warszawa, Wyd. Naukowe PWN.

Wygotski L.S. (1980), Psychologia sztuki. Kraków, Wyd. Lekarskie.

Выготский Л.С. (1983), Трудное детство. В: Т.А. Власова (ред.), Собрание сочинений. Москва, Педагогика.

Выготский Л.С. (1984а), Младенческий возраст. В: Д.Б. Эльконин (ред.), Собрание сочинений. Москва, Пьедагогика.

Выготский Л.С. (1984b), Кризис первого года жизни. В: Д.Б. Эльконин (ред.), Собрание сочинений. Москва, Пьедагогика.

Выготский Л.С. (2001), Лекиии по педологии. Ижевск, Издательский дом Издательство Удмуртского университета.

Wygotski L.S. (2002a), Problem wieku rozwojowego. W: A. Brzezińska, M. Marchow (red.), Wybrane prace psychologiczne II. Dzieciństwo i dorastanie. Poznań, Zysk i S-ka.

Wygotski L.S. (2002b), Wczesne dzieciństwo. W: A. Brzezińska, M. Marchow (red.), Wybrane prace psychologiczne II. Dzieciństwo i dorastanie. Poznań, Zysk i S-ka.

Wygotski L.S. (2002c), Kryzys trzeciego roku życia. W: A. Brzezińska, M. Marchow (red.), Wybrane prace psychologiczne II. Dzieciństwo i dorastanie. Poznań, Zysk i S-ka.

Wygotski L.S. (2002d), Zabawa i jej rola w rozwoju psychicznym dziecka. W: A. Brzezińska, M. Marchow (red.), Wybrane prace psychologiczne II. Dzieciństwo i dorastanie. Poznań, Zysk i S-ka.

Wygotski L.S. (2002e), Kryzys siódmego roku życia. W: A. Brzezińska, M. Marchow (red.), Wybrane prace psychologiczne II. Dzieciństwo i dorastanie. Poznań, Zysk i S-ka.

Wygotski L.S. (2002f), Rozwój zainteresowań w okresie dorastania. W: A. Brzezińska, M. Marchow (red.), Wybrane prace psychologiczne II. Dzieciństwo i dorastanie. Poznań, Zysk i S-ka.

Wygotski L.S. (2002g), Ksztattowanie wyższych form zachowania. W: A. Brzezińska, M. Marchow (red.), Wybrane prace psychologiczne II. Dzieciństwo i dorastanie. Poznań, Zysk i S-ka.

Выготский Л.С., Лурия А.Р. (1993), Этюды по истории поведения: Обезьяна. Примитив. Ребенок. Москва, Педагогика-Пресс. 